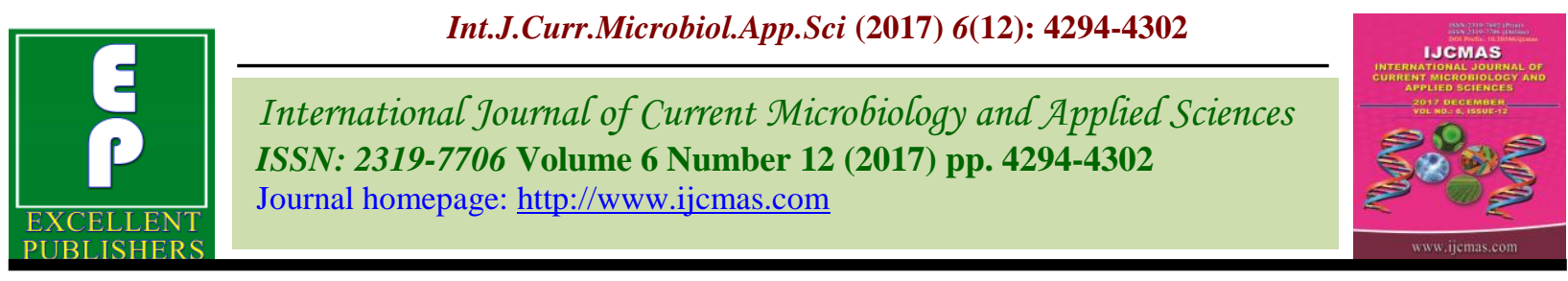

Original Research Article

https://doi.org/10.20546/ijcmas.2017.612.493

\title{
Effect of PGPR on Improving the Germination of Durum Wheat (Triticum durum Desf.) under pH Stress Condition
}

\author{
Bingiala Laloo*, Prashant Kumar Rai and Pramod W. Ramteke
}

Department of Genetics and Plant Breeding, Allahabad School of Agriculture, Sam

Higginbottom Institute of Agriculture, Technology and Sciences, Allahabad- 211007,

Uttar Pradesh, India

*Corresponding author

\section{A B S T R A C T}

\begin{tabular}{|c|c|}
\hline Keywords & influence of Plant Growth Promoting Rhizobacteria on germination of wheat under $\mathrm{pH}$ \\
\hline $\begin{array}{l}\text { Germination, Plant } \\
\text { growth, Genotypes, } \\
\text { Stress. }\end{array}$ & $\begin{array}{l}\text { stress. The genotypes used in this experiment are } 1 . \text { AVKD-3 X RD1008 2. NIDW295 X } \\
\text { HI8636 3. MPD-153 X MASA499 4. DBPY-02-03 X MASA499 5. NIDW-309 X } \\
\text { MASA499 (SHIATS DW2) 6.DBPY-02-03XHI 86388 (SHIATS DW6) 7. NIDW295 X }\end{array}$ \\
\hline Article Info & HIATS DW1) 10 . HI 8653 11. RAJ 1535 12. DBP-01-11 13 . RAJ 6560 and check \\
\hline $\begin{array}{l}\text { Accepted: } \\
28 \text { October } 2017 \\
\text { Available Online: } \\
10 \text { December } 2017\end{array}$ & $\begin{array}{l}\text { variety HD 2009. The } 14 \text { genotypes were inoculated with } 5 \text { PGPR strains viz. 3AAB1, } \\
\text { 3AAB7, 3BAB8, RBA6 and RBA8. The genotypes were first screened for their response } \\
\text { to inoculation with PGPR. The genotypes that performed well were further selected for ph } \\
\text { stress experiment. The results indicated that SHIATS DW3 responded well under pH stress } \\
\text { condition and bacterial culture } 3 \mathrm{AAB} 1 \text { showed the most positive outcome. }\end{array}$ \\
\hline
\end{tabular}

\section{Introduction}

Wheat is a commercially important crop belonging to poaceae family. At present India is the second largest producer of wheat after China. Triticum durum Desf. is the second most important crop after Triticum aestivum, and is the only tetraploid $(2 \mathrm{n}=4 \mathrm{x}=28)$ species of wheat. Durum wheat has a tough horny endosperm, higher carotenoid pigments and better resistance to rusts and karnal bunt as compared to other wheat varieties. The use of micro-organisms in agriculture is at a low level despite the investment in scientific work. Microbial inoculants can be used as an alternative to chemical fertilizers in view of the damaging effect of pesticides and insecticides. Plant Growth Promoting Rhizobacteria (PGPR) are such groups of bacteria that colonize the rhizosphere and improve plant growth (Kloepper and Schroth 1978). When applied to seeds or crops, plant growth promoting rhizobacteria enhance the growth of the plant or reduce the damage from soil borne pathogens. Plant growth promoting rhizobacteria can produce plant growth promoting compounds including phytohormones, auxins, cytokinins and gibberellins (Dashti et al., 2000). The use of PGPR can be used in the future to enhance agricultural production. PGPRs also play an important role in enhancing the root growth, 
and act as efficient microbial competitors in the root zone. Significant effects have been observed in wheat. The use of PGPR reduces soil borne pathogens and thus enhances plant growth directly or indirectly.

The task of increasing wheat production has become overwhelming. There is an urgent need to meet the growing demands under constraints like depleting natural resources, environmental fluctuation and increased risk of epidemic outbreak. Salinity, alkalinity, nutrient deficiency and waterlogging are some of the major constraints affecting wheat cultivation. Low infiltration capacity of the soil, stagnation of water, reduction of soil biological activities, deficiency of bases have a negative impact on germination of wheat seed and soil productivity. An extremely high $\mathrm{pH}$ can occur in sodic soils and even saline soils after heavy rainfall. The effects of high $\mathrm{pH}$ include nutritional disorders such as phosphorous, iron, and zinc deficiencies. An effective approach to deal with the decline in soil health and environment quality must be meted out, and thus promote sustainable agriculture through greater use of biological potential of microbial species.

\section{Materials and Methods}

The experiment was carried out from September 2013-March 2014 at the Biochemistry and Microbiology (PGPR) laboratory Department of Biological Sciences, Sam Higginbottom Institute of Agriculture, Technology and Sciences, Allahabad. The fourteen genotypes of wheat used were 1.AVKD-3 X RD1008 2. NIDW295 X HI8636 3. MPD-153 X MASA499 4. DBPY02-03 X MASA499 5. NIDW-309 X MASA499 (SHIATS DW2) 6.DBPY-0203XHI 86388 (SHIATS DW6) 7. NIDW295 X RD1008 (SHIATS DW3) 8. AVKD2XMASA499 (SHIATS DW5) 9. AVKD2XRD 1008 (SHIATS DW1) 10. HI 865311.
RAJ 1535 12. DBP-01-11 13. RAJ 6560 and check variety HD 2009. The varieties were treated with the bacterial strains of Azobacter (3AAB1, 3AAB7, 3BAB8) and Rhizobium (RBA6 and RBA8).

The nutrient agar was prepared by preparing $0.5 \mathrm{gm}$ Peptone, $0.5 \mathrm{gm}$ yeast extract, $0.1 \mathrm{gm}$ beef extract, $0.5 \mathrm{~g} \mathrm{NaCl}, 2 \mathrm{~g} \mathrm{Agar}$ and $100 \mathrm{ml}$ distilled water at $\mathrm{pH}$ 7.0. The prepared mixture was autoclaved at $121^{\circ} \mathrm{C}$ for 15 minutes. The mixture was allowed to cool down after which it was poured into petriplates. The bacterial strains were inoculated with the help of an inoculating needle into test tubes filled with $9 \mathrm{ml}$ of water. Each variety of wheat was treated with the five different bacterial strains. One test tube was left un-inoculated and treated as control. The test tubes were vigorously shaken to facilitate effective mixing of seeds with the bacterial culture. The test tubes were left standing for 30 minutes. The seeds were then transferred to petri plates lined with germination paper.

\section{Test for $\mathrm{pH}$ stress}

The genotypes that performed well with the bacterial strains were further selected to test their performance under varying $\mathrm{pH}$ stress. For screening the tolerance of the wheat genotypes and PGPR to different $\mathrm{pH}$, the distilled water was adjusted to 5 different $\mathrm{pH}$ levels $(\mathrm{pH} 5,6,7,8,9)$. The acidity or alkalinity of the water was maintained by $1 \mathrm{~N}$ $\mathrm{HCl}$ or $1 \mathrm{M} \mathrm{NaOH}$ respectively. Each genotype was tested with the respective bacterial strain at different $\mathrm{pH}$ levels. A control experiment was maintained with neutral $\mathrm{pH}(\mathrm{pH} 7)$. The observations were made on the $3^{\text {rd }}, 5^{\text {th }}, 7^{\text {th }}$ and $9^{\text {th }}$ days after inoculation. The inoculated plants were left at room temperature. The treatments were frequently watered to avoid drying. Care was taken to ensure that the plants were watered 
with the suitable $\mathrm{pH}$ water. The observations were recorded on $3^{\text {rd }}, 5^{\text {th }}, 7^{\text {th }}$ and $9^{\text {th }}$ days after inoculation (DAI). The number of seeds used for germination percentage test was 25 and the number of seeds used for root and shoot length observation was 10 with 3 replications. The germination percentage was calculated according to the prescribed standards given by ISTA (1999).

\section{Results and Discussion}

The results obtained in the present investigation "Effect of PGPR on improving the germination of durum wheat (Triticum durum Desf.) under ph stress condition" was carried out from September 2013-March 2014 at the Biochemistry and Microbiology (PGPR) laboratory Department of Biological Sciences, Sam Higginbottom Institute of Agriculture, Technology and Sciences, Allahabad. The experiment was carried out with Completely Randomized Design One way ANOVA. From the table values obtained, the varieties and PGPR strains identified as best performing were as follows. The salient results of the experiment and the conclusion drawn from it are summarized here as follows:

The mean sum of squares due to the genotypes was significant for all the characters studied. The results showed significant difference was observed at 5\% level of significance.

At $\mathrm{pH}$ 5, SHIATS DW3 and PGPR strain 3AAB1, showed maximum germination percentage $(96 \%)$ and better performance over the germination percentage at neutral $\mathrm{pH}$ $(76 \%)$.

At $\mathrm{pH}$ 6, SHIATS DW3 and PGPR strain 3AAB1 showed maximum germination percentage $(92 \%)$ and better performance over germination percentage at neutral $\mathrm{pH}$ $(76 \%)$, indicating significant increase in germination percentage.

Table.1 List of responsive wheat genotypes and PGPR strains

\begin{tabular}{|ll|l|}
\hline \multicolumn{2}{|l|}{ Genotype } & \multicolumn{1}{|c|}{ PGPR Strain } \\
\hline i.) & NIDW295XRD1008 & 3AAB1 \\
\hline ii.) & AVKD-2XMASA499 & 3AAB1, RBA8 \\
\hline iii.) & RAJ1535 & 3AAB1, RBA8 \\
\hline iv.) & AVKD-2XRD1008 & RBA8 \\
\hline v.) & DBPY-02-03XHI8636 & 3AAB7, 3BAB8, RBA6 \\
\hline vi.) & NIDW309XMASA499 & 3AAB7 \\
\hline vii.) & DBPY-02-03XMASA499 & 3AAB1 \\
\hline viii.) & HD2009 & 3AAB1,RBA8 \\
\hline
\end{tabular}

The effect of the selected PGPR strains on the seedling growth parameters (germination) of the selected genotypes at varying $\mathrm{pH}$ stress was further tested. 
Table.2 Effect of PGPR on seed germination of durum wheat under $\mathrm{pH}$ stress

\begin{tabular}{|l|l|c|c|c|c|c|}
\hline \multirow{2}{*}{ Genotypes } & \multirow{2}{*}{ Culture } & \multicolumn{5}{|c|}{ Percent germination \% } \\
\cline { 3 - 7 } & & $\mathbf{p H 5}$ & $\mathbf{p H 6}$ & $\mathbf{p H 7}$ & $\mathbf{p H 8}$ & $\mathbf{p H 9}$ \\
\hline SHIATS DW3 & Control & 40 & 60 & 80 & 72 & 64 \\
\hline & 3AAB1 & 96 & 92 & 76 & 76 & 92 \\
\hline SHIATS DW5 & Control & 92 & 84 & 95 & 60 & 60 \\
\hline & 3AAB1 & 72 & 56 & 76 & 76 & 78 \\
\hline & RBA8 & 69 & 68 & 76 & 76 & 60 \\
\hline RAJ 1535 & Control & 68 & 68 & 44 & 48 & 48 \\
\hline & 3AAB1 & 72 & 60 & 60 & 44 & 96 \\
\hline & RBA8 & 60 & 36 & 40 & 40 & 16 \\
\hline SHIATS DW1 & Control & 40 & 72 & 96 & 72 & 64 \\
\hline & RBA8 & 72 & 84 & 96 & 80 & 84 \\
\hline SHIATS DW6 & Control & 72 & 56 & 48 & 68 & 27 \\
\hline & 3AAB7 & 80 & 60 & 76 & 76 & 72 \\
\hline & 3BAB8 & 32 & 52 & 48 & 52 & 48 \\
\hline & RBA6 & 52 & 16 & 40 & 48 & 88 \\
\hline SHIATS DW2 & Control & 76 & 48 & 36 & 48 & 72 \\
\hline & 3AAB7 & 40 & 72 & 60 & 56 & 80 \\
\hline DBPY-02-03XMASA499 & Control & 48 & 64 & 72 & 68 & 92 \\
\hline & 3AAB1 & 76 & 80 & 96 & 68 & 96 \\
\hline HD2009 & Control & 60 & 52 & 65 & 60 & 48 \\
\hline & 3 AAB1 & 68 & 60 & 76 & 72 & 52 \\
\hline & RBA8 & 72 & 64 & 52 & 72 & 92 \\
\hline & Mean & 64.76 & 62.09 & 67.19 & 63.42 & 68.047 \\
\hline & Max & 96 & 92 & 96 & 80 & 96 \\
\cline { 3 - 7 } & Min & 32 & 16 & 36 & 40 & 16 \\
\hline & CV & 1.544 & 1.61 & 1.488 & 1.577 & 1.47 \\
\hline & CD $(5 \%)$ & 1.654 & 1.654 & 1.654 & 1.654 & 1.654 \\
\hline
\end{tabular}

Mean of 3 replicates

Table.3 Germination percentage of genotypes at neutral $\mathrm{pH}$

\begin{tabular}{|l|l|l|}
\hline Neutral $\mathrm{pH}$ & Number of genotypes & $\begin{array}{l}\text { Number of genotypes with } \\
\text { high germination percentage }\end{array}$ \\
\hline $\mathrm{pH} 7$ & 8 & $5(62.5 \%)$ \\
\hline
\end{tabular}

Table.4 Germination percentage of genotypes at acidic stress condition

\begin{tabular}{|l|l|l|}
\hline Acidic $\mathrm{pH}$ & Number of genotypes & $\begin{array}{l}\text { Number of genotypes with } \\
\text { high germination percentage }\end{array}$ \\
\hline $\mathrm{pH} 5$ & 8 & $5(62.5 \%)$ \\
\hline $\mathrm{pH} 6$ & 8 & $3(37.5 \%)$ \\
\hline
\end{tabular}


Table.5 Germination percentage of genotypes at alkaline stress conditions

\begin{tabular}{|l|c|c|}
\hline Alkaline $\mathrm{pH}$ & Number of genotypes & $\begin{array}{c}\text { Number of genotypes with } \\
\text { high germination percentage }\end{array}$ \\
\hline $\mathrm{pH} 8$ & 8 & $2(25 \%)$ \\
\hline $\mathrm{pH} 9$ & 8 & $5(62.5 \%)$ \\
\hline
\end{tabular}

Fig.1 Germination percentage of SHIATS DW3 under pH stress

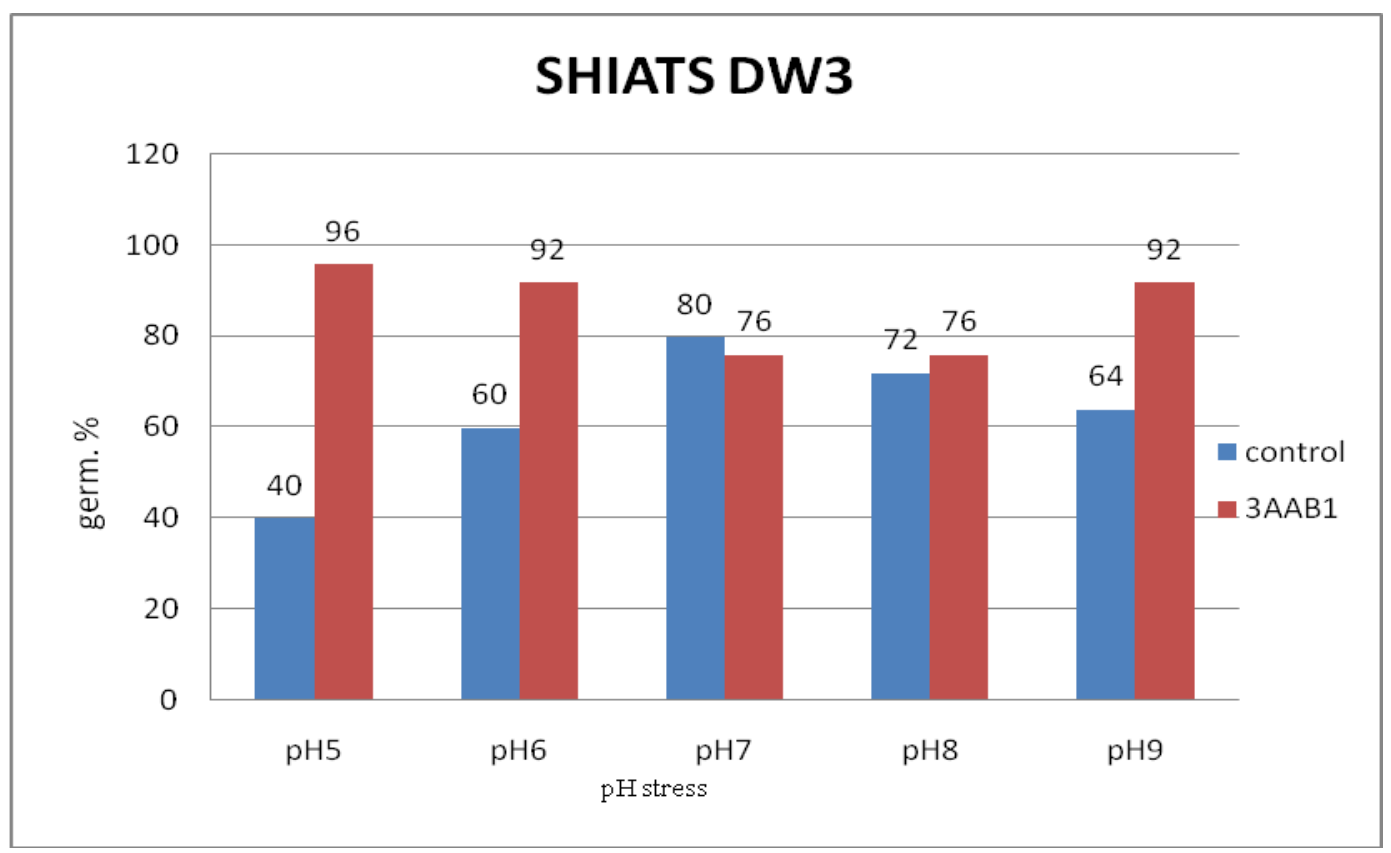

Fig.2 Germination percentage of SHIATS DW5 under pH stress

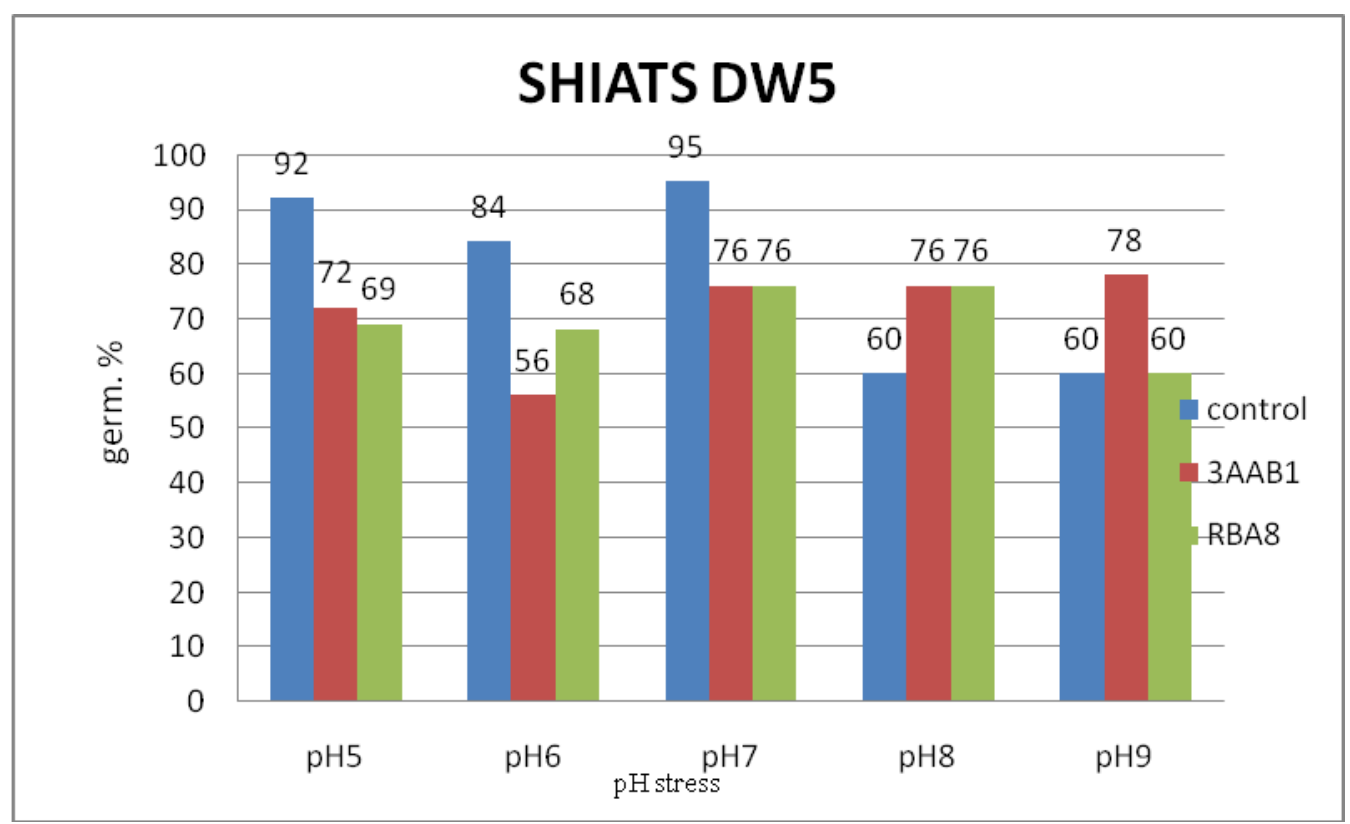


Fig.3 Germination percentage of RAJ 1555 under pH stress

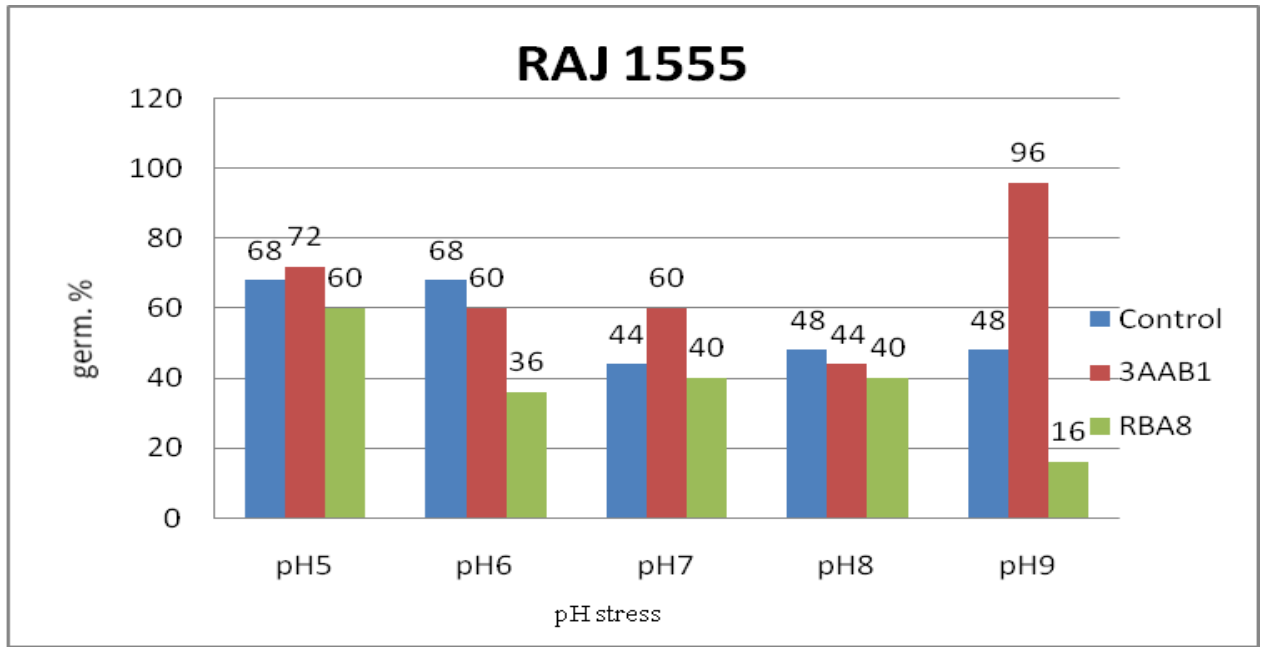

Fig.4 Germination percentage of SHIATS DW6 under pH stress

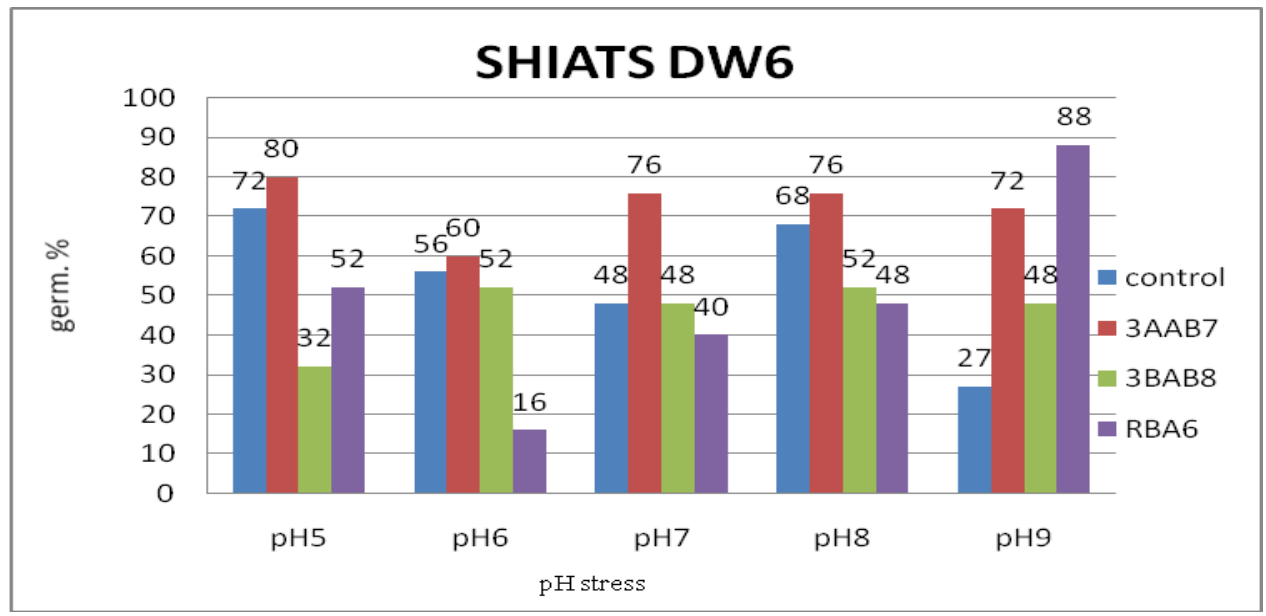

Fig.5 Germination percentage of SHIATS DW2 under pH stress

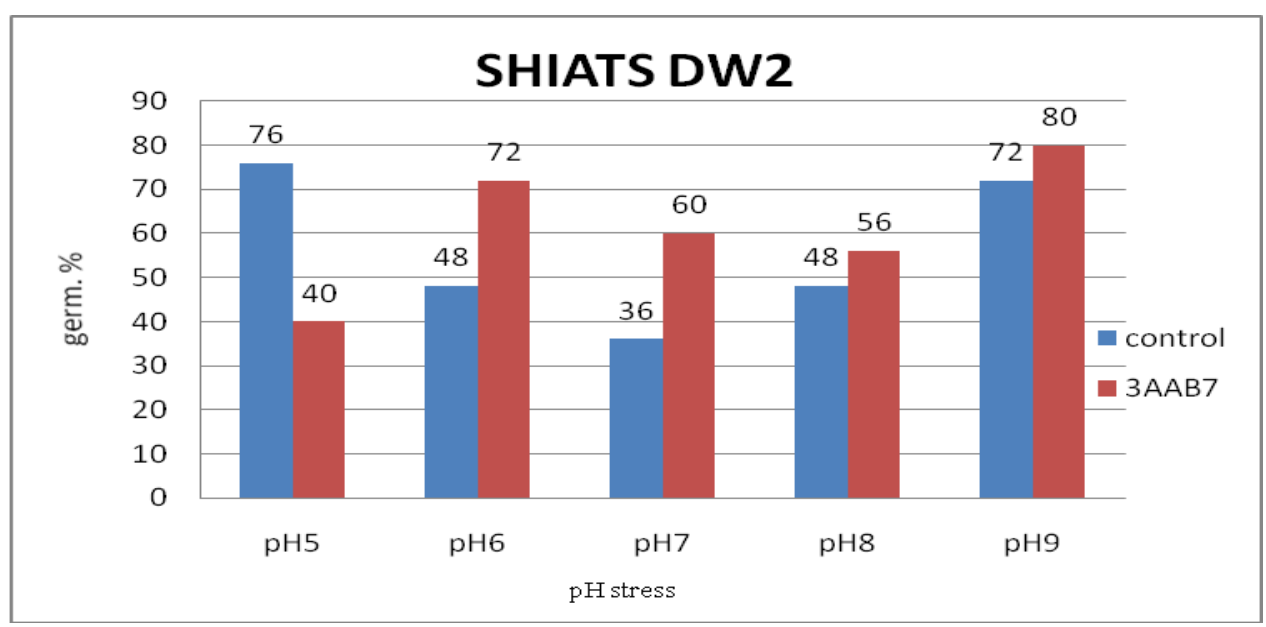


Fig.6 Germination percentage of DBPY-02-03 XMASA499 under pH stress

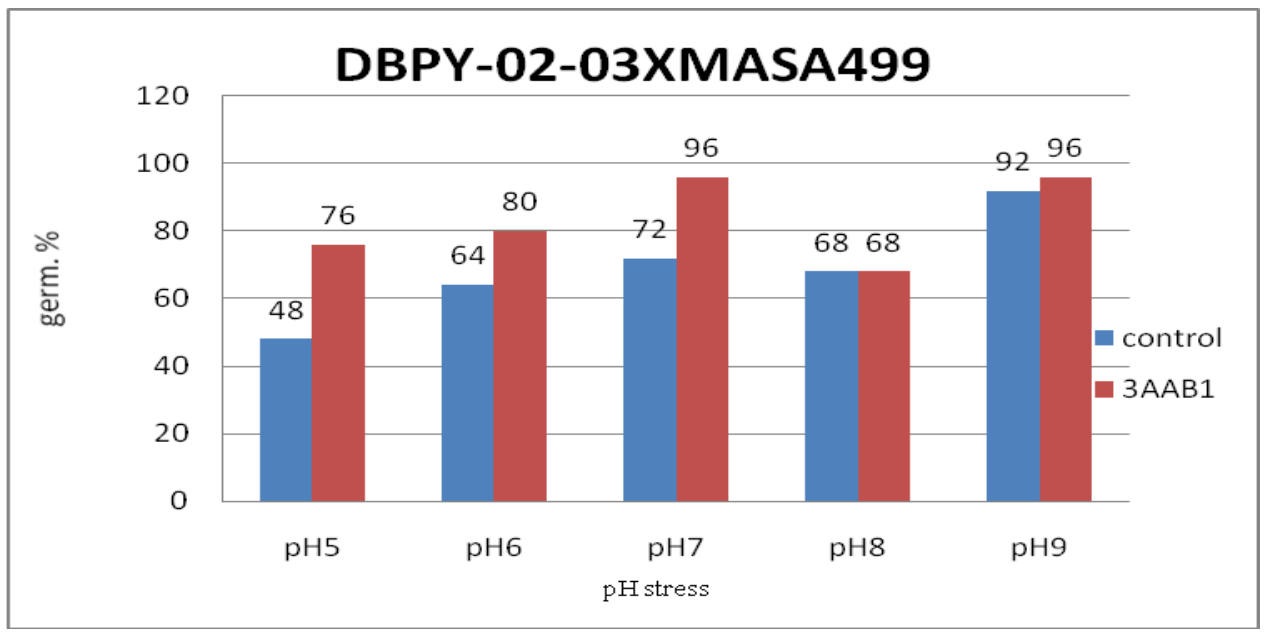

Fig.7 Germination percentage of SHIATS DW1 under pH stress

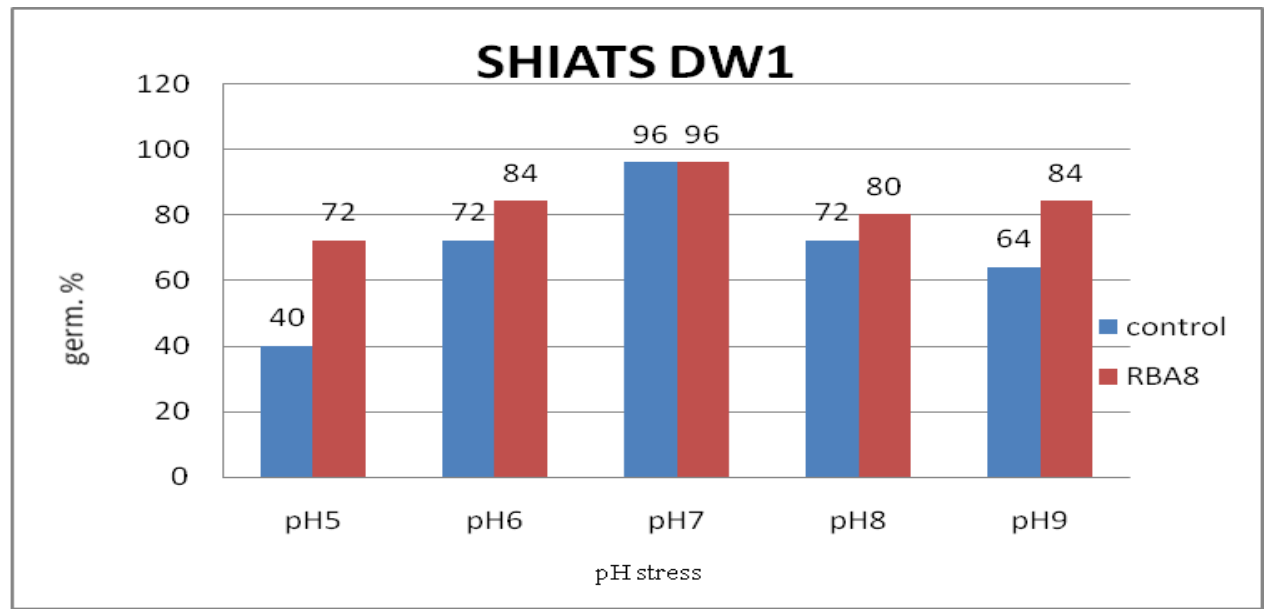

Fig.8 Germination percentage of HD2009 under pH stress

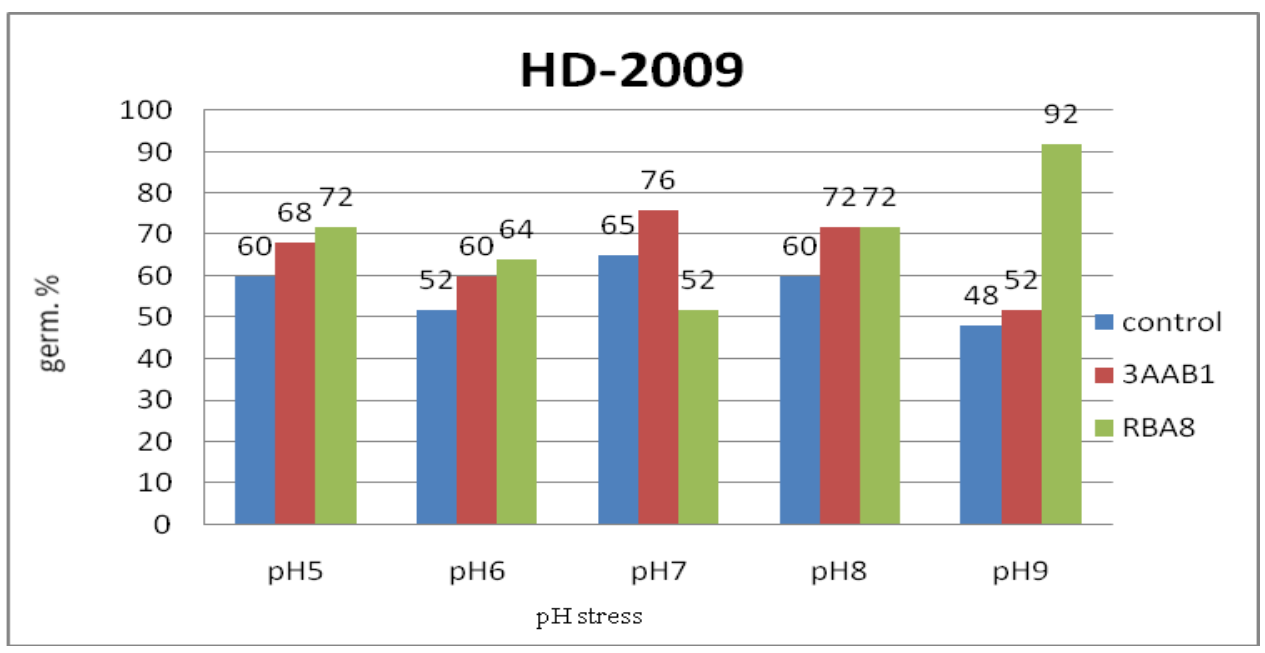


At $\mathrm{pH}$ 8, SHIATS DW6 with PGPR strain 3BAB8 showed a higher germination percentage $(52 \%)$ as compared to the neutral $\mathrm{pH}(48 \%)$, indicating significant increase over the germination percentage.

At pH 9, RAJ1535 and PGPR strain 3AAB1, DBPY-02-03XMASA499 and 3AAB1 showed maximum germination percentage $(96 \%)$ and better performance over the germination percentage at neutral $\mathrm{pH}(60 \%)$, indicating significant increase over the germination percentage.

$62.5 \%$ of the genotypes germinated under neutral $\mathrm{pH}$ condition. Under acidic stress condition, $62.5 \%(\mathrm{pH} \mathrm{5)}$ and $37.5 \%(\mathrm{pH} \mathrm{6})$ of genotypes showed higher germination percentage as compared to the neutral $\mathrm{pH}$ while $25 \%(\mathrm{pH}$ 8) ad $62.5 \%(\mathrm{pH} 9)$ genotypes showed higher germination percentage under alkaline condition as compared to performance at neutral $\mathrm{pH}$ (Table 3-5).

It was observed from table 1 that $62.5 \%$ of the genotypes germinated under neutral $\mathrm{pH}$ condition. As indicated in table 2, under acidic stress condition, $62.5 \%(\mathrm{pH} 5)$ and 37.5 $\%$ ( $\mathrm{pH}$ 6) of genotypes showed higher germination percentage as compared to the neutral $\mathrm{pH}$ while $25 \%(\mathrm{pH} 8)$ and $62.5 \%(\mathrm{pH}$ 9) genotypes showed higher germination percentage under alkaline condition as compared to performance at neutral $\mathrm{pH}$. Similar results were reported by Gholami et $a l ., 2009$ in field grown maize inoculated with plant growth promoting rhizobacteria.

The figures 1-8 represent the response of durum wheat genotypes to PGPR strains.

It can be concluded from the present investigation that PGPR strains have a significant effect on the germination of durum wheat genotypes. The germination percentages of the genotypes at different levels of $\mathrm{pH}$ stress were significantly improved when compared with the control. Thus it can be derived that PGPR has a positive effect in improving the germination percentages of wheat genotypes under $\mathrm{pH}$ stress condition. Okon and Vanderleyden (1997) suggested that the secretion of plant growth-promoting substances by the bacteria could be responsible for the beneficial effects of PGPR. The germination parameters were observed to know the rapidity of germination which helped in reflecting the quality of seeds and response to PGPR inoculation. The results indicated that the germination percentage of the genotypes inoculated with PGPR showed better performance over the neutral $\mathrm{pH}$. The germination percentage of wheat seeds inoculated with PGPR also showed better emergence over control (uninoculated genotypes). Similar results have been recorded by Ashrafuzzaman et al., (2009) in rice seeds inoculated with PGPR whereby the rice seeds showed an increase in germination by 2.3 to $14.7 \%$ over control. Similar improvement in germination parameters have been reported in several crops such as sorghum and pearl millet by Raju et al., (1999) and Niranjan et al., $(2003,2004)$. The germination percentage of SHIATS DW3 treated with 3AAB1 showed a germination percentage of 96 percent as compared to the control. Thus this particular treatment combination (SHIATS DW3 with 3AAB1) displayed the beneficial effects of inoculation with PGPR in durum wheat. The increase in the germination percentage of the wheat genotypes may be due to the increased synthesis of hormones like gibberellins which trigger the activity of certain enzymes that promote early germination.

\section{References}

Annual Report 2012-2013, Directorate of Wheat Research 
Ashrafuzzaman, M., Hossen, F.A., Razi M.I., Hoque, A., Zahurul, M., Shahidullah, S.M. and Meon,S. (2009). Efficiency of plant growth-promoting rhizobacteria (PGPR) for the enhancement of rice growth, African Journal of Biotechnology, 8 (7):1247-1252.

Dashti, N., Prithviraj, B., Zhou, X. M., Hynes, R., and Smith, D.L. (2000). Combined effects of plant growth promoting rhizobacteria and genistein on nitrogen fixation activity in soybean at suboptimal root zone temperatures. Journal of Plant Nutrition 23: 593-604

Gholami, A., Shahsavani, S., and Nezarat, S. (2009) The Effect of Plant Growth Promoting Rhizobacteria (PGPR) on Germination, Seedling Growth and Yield of Maize. World Academy of Science, Engineering and Technology, 3:1-26.

International Seed Testing Association (ISTA). (1999). International Rules for Seed Testing. Seed Science and Technology, 13: 300-513.

Kloepper, J.W and Schroth, M.N. (1978) Plant growth promoting rhizobacteria on radishes, In: Proceedings of the 4th international conference on plant pathogenic bacteria, Angers, France, 879-882

Niranjan, S.R., Shetty, N.P. and Shetty, H.S. (2004). Seed biopriming with Pseudomonas fluorescens isolates enhances growth of pearl millet plants and induces resistance against downy mildew. Journal of Pest Management, 50: 41-48.

Okon, Y. and Vanderleyden, J. (1997). Root associated Azospirillum sp. can stimulate plants. American Society for Microbiology News, 63:366-370.

Raju, N.S., Niranjana, S.R, Janardhana, G.R., Prakash, H.S., Shetty, H.S. and Mathur, S.B. (1999). Improvement of seed quality and field emergence of Fusarium moniliforme infected sorghum seeds using biological agents. Journal of the Science of Food and Agriculture, 79: 206-212.

Singh, V., Singh, S.P., Singh, S., and Shivay, Y.S. (2013). Growth, yield and nutrient uptake by wheat (Triticum aestivum) as affected by biofertilizers, FYM and nitrogen. Indian Journal of Agricultural Sciences, 83(3): 331-4.

\section{How to cite this article:}

Bingiala Laloo, Prashant Kumar Rai and Pramod W. Ramteke. 2017. Effect of PGPR on Improving the Germination of Durum Wheat (Triticum durum Desf.) under $\mathrm{pH}$ Stress Condition. Int.J.Curr.Microbiol.App.Sci. 6(12): 4294-4302.

doi: https://doi.org/10.20546/ijcmas.2017.612.493 